\title{
SEBAB, AKIBAT DAN TERAPI PELAKU HOMOSEKSUAL
}

\author{
ABDURRAAFI' MAUDUDI DERMAWAN \\ Program Studi Farmakokimia \\ Pascasarjana ITB (Institut Teknologi Bandung) Bandung \\ Email : rafi.derma@gmail.com
}

\begin{abstract}
Homosexual is an attraction feeling, sexually, to people of one's own sex. Based on the internal factor, homosexual people - from teenager age - basically have feelings and tendency only to men not women. Meanwbile, from the external aspect, homosexual is done because of friends, lifestyle, or environment. Furthermore, the internal aspect of homosexual is due to genetic factor. Children who were born with genetic and hormonal disorders would grow up based on their sexual deviance. Besides, the external aspect of homosexual comes from outside. In addition, the external factors could be begun from parental education, neighborhood, physic or psychological abuse, socialmedia effects, and friendships. As a result, the homosexual doer would bave unnecessary future, morally or socially. Moreover, the psychological and religious approach would be needed. The therapy is demanded in order to restore the awareness of homosexual doers about their true identity as human.
\end{abstract}

Keywords: Homosexual, Cause, Effect, Therapy

\section{PENDAHULUAN}

Keberadaan kaum homoseksual dalam kehidupan manusia telah mencul berabadabad silam seiring dengan munculnya kehidupan manusia di muka bumi ini. Kehadirannya ditengah-tengah kehidupan manusia, baik secara tersembunyi maupun terbuka. Kehadiran mereka sepertinya tidak diharaukan lagi oleh masyarakat di sekitarnya. Salah satu penyebab maraknya perkembangan kaum homoseksual di masyarakat adalah ketidakpedulian masyarakat terhadap perilaku ini. Padahal perilaku homoseksual sendiri sangat bertentangan dengan moral dan nilai-nilai agama manapun di dunia. Oleh sebab itu perilaku homoseksual menjadi penyakit sosial yang sulit diobati.

Kartono (1989: 247) mendefinisikan homoseksual sebagai relasi seks jenis kelamin yang sama, atau rasa tertarik dan mencintai jenis seks yang sama. Homoseksual dapat dimasukkan ke dalam kajian abnormalitas seksual yang terdapat dalam psikologi abnormal. ${ }^{1}$ Selanjutnya, Dede Oetomo (2001: 6-7) memberikan definisi homoseksual sebagai orientasi atau pilihan seks yang diarahkan kepada seseorang yang berjenis kelamin sama atau ketertarikan orang secara emosional dan seksual kepada seseorang dari jenis kelamin yang sama. ${ }^{2}$ Homoseksual berasal dari kata bomo yang berarti sama dan sexual yang berarti hubungan seksual atau berhubungan dengan kelamin. Hubungan seksual adalah orang yang konsisten tertarik secara seksual, romantik, dan afektif terhadap orang yang memiliki jenis kelamin yang sama dengan mereka. Ada dua istilah terdapat pada orang yang mempunyai

\footnotetext{
${ }^{1}$ Kartini Kartono, Psikologi Abnormal dan Abnormalitas Seksual, (Bandung: CV. Mandar Maju. 1989), hlm. 247.

${ }^{2}$ Dede Oetomo, Memberi Suara Pada yang Bisu, (Yogyakarta: Galang Press. 2001), hlm. 6-7.
} 
kecenderungan homoseksual yaitu lesbian dan gay dan istilah ini sangat terkenal di lingkungan masyarakat. ${ }^{1}$

Dari beberapa definisi homoseksual di atas, homoseksual didasari oleh dua orientasi, keinginan, dan kebutuhan (faktor internal). Pertama, Seorang homoseksual yang pada dasarnya dari sejak remaja mempunyai perasaan dan kecenderungan hanya kepada laki-laki saja dan tidak tertarik kepada perempuan. Pertumbuhan fisiknya pun tidak normal seperti remaja laki-laki pada umumnya. Ada bagian tertentu yang tidak tumbuh dengan optimal, misalnya alat kelamin laki-lakinya tidak seperti laki-laki pada umumnya, sifatnya cenderung keperempuanan. Bahkan kelembutan pribadinya bisa melebihi kelembutan perempuan pada umumnya. Kepribadian homoseksual ini terus melekat sampai dewasa, sehingga akhirnya dia memilih seorang laki-laki sesama jenisnya sendiri untuk menjadi pasangan dekatnya. Kelainan orientasi seksual seperti ini diakibatkan adanya kelainan hormonal dan genetik yang memang dibawa sejak lahir.

Kedua, homoseksual yang diakibatkan oleh pengaruh lingkungan (faktor eksternal). Seseorang dengan orientasi homoseksual pada awalnya pertumbuhan dan perkembangan kepribadiannya adalah normal. Secara fisik dan psikis tumbuh dan berkembang normal. Namun karena lingkungan pergaulannya sehari-hari yang kurang baik, akhirnya dapat membentuk orientasi homoseksual, seperti sering menonton video seks homo (ada keinginan untuk merasakan), terlalu bergaul terlalu dekat dengan teman lakilaki sesama jenisnya sendiri, sering mengalami putus hubungan cinta dengan teman perempuan dan merasa nyaman berada dekat dengan teman laki-laki ketimbang perempuan, sejak kecil diberi pakaian, mainan, dan teman perempuan oleh orang tua, pernah mendapat kekerasan seksual (sodomi), dan lain-lain.

Sebaliknya lesbian merupakan istilah yang menggambarkan seorang perempuan yang secara emosi dan fisik tertarik dengan sesama perempuan, sedangkan gay merupakan istilah untuk menyebutkan lelaki yang menyukai sesama lelaki sebagai partner seksual, serta memiliki ketertarikan baik secara perasaan atau erotik, baik secara dominan atau eksklusif dan juga dengan ataupun tanpa adanya hubungan fisik, namun lebih umum kata homoseksual erat kaitannya dengan stigma untuk menunjukkan seseorang lakilaki yang menyukai sesama jenis².

Demikian pula sifat dan kepribadian seorang lesbian dapat disebabkan adanya dua faktor, baik faktor internal maupun eksternal. Dari faktor internal, seorang lesbi dipengaruhi oleh faktor bawaaan, seperti adanya kelainan hormonal yang dapat mempengaruhi pertumbuhan fisik dan psikis anak. Secara fisik, pertumbuhan dan perkembangannya tidak normal sebagaimana layaknya seorang perempuan remaja atau dewasa. Kemungkinan payudaranya tidak seperti perempuan remaja atau dewasa lainnya. Begitu pula yang berhubungan dengan organ seks dan reproduksi lainnya, seperti tidak mengalami menstruasi dan ada kelainan pada rahim dan vaginanya. Dari segi fisik yang dimiliki oleh seorang lesbi akan menyebabkan dia memiliki orientasi seks lesbian. Seorang lesbi tidak memiliki ketertarikan dengan laki-laki lawan jenisnya, justru sebaliknya dia akan tertarik

${ }^{1}$ Ridho Ariono. Emotional Intellegence And Psychological Welbeing in Male Friendly, (Gunadarma University Library: Jurnal Tidak Diterbitkan. 2011), hlm. 3.

2 Putu Hening Wedanthi dan I. G. A. Diah Fridari. Dinamika Kesetiaan Pada Kaum Gay. Jurnal Psikologi Udayana. Vol. 1, No. 2, 363-371. 2014), hlm. 364. 
pada perempuan sejenisnya. Seorang perempuan lesbi akan merasa bahwa dirinya adalah seorang laki-laki. Sejak kecil, dia menyukai mainan dan pakaian lakilaki. Dia sering memerankan sifat laki-laki dalam dirinya, seperti kalau dalam permainan, dia akan memerankan peran ayah atau kakak laki-laki. Begitupun di rumah, dia lebih menyenangi pekerjaan yang biasa dilakukan oleh anak laki-laki dan seorang ayah.

Seorang lesbi juga dipengaruhi oleh faktor dari luar, yaitu faktor lingkungan. Keinginan orang tua memiliki anak laki-laki menyebabkan terjadinya pola pendidikan yang salah pada anak perempuan, seperti anak perempuan diberi pakaian dan mainan lakilaki. Anak perempuan lebih menyenangi dan bergaul dengan ayah dan teman lakilaki, sehingga kebiasaan seperti ini akan membentuk sifat dan kepribadian seorang laki-laki pada anak perempuan. Ketika remaja dan dewasa, seorang lesbi secara tidak sadar akan memberi statuspada dirinya bahwa dirinya adalah seorang lakilaki. Sifat dan kepribadiannya seperti ini akan memunculkan orientasi seksual lesbian pada dirinya. Dia hanya tertarik dan menyenangi perempuan sesama jenisnya saja.

Faktor lingkungan lain juga menumbuhkan benih-benih lesbian pada seseorang adalah seringkali mengalami putus cintapada seorang lakilaki dan mengalami kekerasan seksual dari seorang laki-laki, sehingga lambat laun dia akan membenci sosok laki-laki dalam kehidupannya, justru sebaliknya seorang lesbi seperti ini akan merasa tenang dan nyaman berada didekat kaum perempuan. Perasaan seperti ini akan memicu pada orientasi seksual lesbian pada dirinya. Faktor lingkungan lainnya seperti sering menonton video porno (video seks lesbi) akan menyebabkan keinginan mencoba-coba yang pada akhirnya seorang perempuan normal menyukai seksual lesbian

Homoseksual adalah orientasi seksual yang menyimpang, yaitu seseorang yang menyukai sesama jenisnya sendiri. Laki-laki menyukai laki-laki (Gay) dan perempuan menyukai perempuan (lesbian). Kehidupan mereka pada umumnya sama dengan pola kehidupan pada masyarakat umumnya. Mereka melakukan aktivitas kerja dan rutinitas kehidupan lainnya. Namun seks bebas dan penyimpangan seks yang dilakukan inilah yang dilarang keras, baik oleh hukum positif Indonasia, agama, dan norma masyarakat. Kebanyakan kaum gay atau lesbian tidak mempunyai keluarga (suami/istri dan anak). Pada usia setengah abadpun mereka memilih hidup sendiri dan tanpa keluarga. Kebahagiaan mereka adalah ketika mereka hidup bersama pasangannya, bukan dari keluarga sejati yang dibentuk berdasarkan pernikahan sah.

Perkembangan gaya dan perilaku homoseksual saat ini sudah pada level yang mengkhawatirkan karena menjangkiti para remaja dan generasi muda saat ini. Bahkan tindak kekerasan pada anak akibat perilaku seksual terjadi di manamana. Apabila keadaan ini dibiarkan saja, baik oleh masyarakat maupun pemerintah, maka akan semakin rusaklah bangsa ini dan mau dikemanakan nasib dan masa depan generasi muda kita. Menurut Trianingsih $^{1}$ bahwa hasil penelitian menunjukkan hubungan anak lakilaki dan laki-laki di negara Peru dengan angka 10\%-60\%, di Brazil 5-13\%, di Amerika 10-14\%, di Botzwana 15\%, dan di Thailand 6-16\%. Beberapa laki-laki menyadari bahwa dirinya homoseksual atau gay. Mereka melakukan hubungan seksual jangka panjang dengan wanita dan kadang-

1 Aput Hartono, Faktor Resiko Kejadian Penyakit Menular Seksual (PMS) Pada Komunitas Gay Mitra Strategis Perkumpulan Keluarga BerencanaIndonesia (PKBI) Yogyakarta, (Surakarta: Fakultas Kesehatan Masyarakat Universitas Muhammadiyah Surakarta. Skripsi. 2009), hlm. 2. 
kadang melakukan hubungan seks dengan pria dan sering tanpa diketahui pasangan wanitanya. Dalam kasus ini, hubungan seks mungkin dilakukan antara pria, karena memang hanya pria saja yang tersedia sebagai pasangan seks.'

Menurut Fauzi, bahwa berdasarkan hasil penelitian dari National Center for Health Research, di Amerika tahun 2002 sekitar 4,4\% masyarakat melakukan hubungan homoseksual, dengan usia 15- 44 tahun. Berdasarkan hasil statistik di Indonesia, menunjukkan bahwa sekitar 8-10 juta pria pernah terlibat dalam hubungan homoseksual.

Berdasarkan hasil penelitian di atas bahwa pelaku gay, khususnya pada usia remaja sangat rentan menjadi pelaku homoseksual. Hal ini sangat memprihatinkan karena disamping masa depan mereka akan rusak, jauh dari nilai-nilai agama, juga mereka sangat rentan terkena penyakit menular, HIV, dan lainnya. Menurut Fritzpatrick ${ }^{3}$ dari hasil penelitian terhadap 356 orang Gay yang diwawancarai 40\%, diantaranya beresiko terhadap penularan PMS (penyakit menular seksual). Menurut Hirshfield ${ }^{4}$ bahwa komunitas gay dipandang rentan terhadap penularan PMS dan HIV/AIDS. Mengingat perilaku seksual komunitas gay yang cenderung bebas dan bergantiganti pasangan serta rendahnya informasi tentang kesehatan reproduksi. Berdasarkan hasil penelitian menunjukkan bahwa umur 1829 tahun sebanyak 45\% telah menjadi mitra seksual dan ditemukan $9 \%$ diantaranya positif HIV/AIDS.

Selanjutnya menurut Raharjo, PMS menjadi sangat serius, karena dapat menyerang dalam cakupan luas ke seluruh penjuru dunia. PMS juga dapat dengan mudah menyebar dari satu orang kepada orang lain. PMS yang dapat menularkan pada komunitas homoseksual adalah Gonorhoe, Sipilis, dan Harpes kelamin. Tetapi yang paling besar diantaranya adalah HIV/AIDS, karena mengakibatkan kematian 4 pada penderitanya, karena AIDS tidak bisa diobati dengan antibiotik.

Permasalahan seksual pada pelaku homoseksual pada usia remaja perlu mendapat perhatian khusus. Pergaulan bebas dan kurangnya perhatian orang tua pada anak remajanya dapat menimbulkan bahaya kesehatan reproduksi, yaitu tertularnya berbagai jenis penyakit kelamin. Selain meningkatkan perhatian orang tua pada anak remajanya, juga perlu ditingkatkan pendekatan keagamaan, dan bimbingan pemeliharaan alat-alat reproduksi dan bimbingan penyakit kelamin.

\section{SEBAB-SEBAB TIMBULNYA PERILAKU HOMOSEKSUAL}

Perilaku homoseksual tidak muncul secara tiba-tiba pada diri seorang homo, akan tetapi ada beberapa faktor penyebabnya, yaitu faktor internal dan eksternal. Faktor internal adalah faktor bawaan dari awal pembentukan sygot atau pertemuan sel sperma dan sel telur, sampai pada saat kehamilan dan kelahiran. Anak yang lahir dengan kelainan genetik dan hormonal, selanjutnya akan tumbuh dan berkembang menjadi remaja dan dewasa berdasarkan kelainan yang dimilikinya. Misalnya anak perempuan yang lahir dengan kelainan genetik dan hormonal, maka anak perempuan bisa tumbuh dan berkembang dengan fisik dan kepribadian cenderung seperti anak laki-laki. Begitu pula sebaliknya, anak

\footnotetext{
${ }^{1}$ Ibid., hlm. 2

2 Ibid., hlm. 2

3 Ibid., hlm. 2

${ }^{4}$ Ibid., hlm. 4
} 
laki-laki dengan kelainan genetik dan hormonal akan tumbuh dan berkembang dengan fisik dan kepribadian yang cenderung seperti perempuan.

Sedangkan faktor eksternal adalah faktor-faktor yang disebabkan oleh situasi dan kondiri di luar diri anak. Termasuk faktor dari luar diri anak, yaitu pendidikan orang tua, lingkungan pergaulan, kekerasan fisik atau psikis yang dialami anak, depresi atau stres yang dialami anak, pengaruh media elektronik maupun media cetak dan ikut-ikutan gaya temanteman di sekitarnya. Pendidikan yang salah pada anak dapat menyebabkan perubahan kepribadian pada diri anak, misalnya anak perempuan dididik ala laki-laki, maka anak perempuan cenderung akan menjadi anak laki-laki, demikian pula sebaliknya anak laki-laki dididik ala anak perempuan, maka anak lakilaki cenderung menjadi anak perempuan. Ditambah lagi dengan pergaulan yang salah akan memperkuat jadi diri seorang homo. Anak perempuan banyak bergaul dengan anak laki-laki, sebaliknya anak laki-laki banyak bergaul dengan anak perempuan.

Kekerasan fisik dan psikis yang dialami oleh anak akan menyebabkan kebencian dan dendam pada status diri seseorang. Anak perempuan yang sering kali mengalami kekerasan fisik dan psikis dari seorang ayah dan kemudian berlanjut mendapat kekerasan lainnya dari pacarnya, maka kemungkinan dalam diri anak perempuan tumbuh kebencian dan dendam pada sosok laki-laki, sebaliknya ketika dia merasa aman dan nyaman berada didekat para perempuan, maka lambat laun dia akan menyukai dan tertarik pada kaum sejenisnya. Perasaan suka dan cintapun lambat laun akan memunculkan orientasi seksual lesbian. Sebaliknya bilamana seorang anak laki-laki seringkali mendapat kekerasan fisik atau psikis dari ibu atau pacarnya maka akan tumbuh dalam dirinya suatu kebencian dan dendam pada sosok perempuan. Dan bilamana tumbuh rasa aman dan nyaman dalam dirinya ketika dia dekat pada sosok laki-laki, maka lambat laun akan tumbuh perasaan suka, cinta dan bahkan orientasi homoseksual.

Pengaruh stres dan depresi yang dialami seseorang juga dapat menjadi penyebab terjadi perilaku homoseksual. Seseorang yang kurang memiliki keimanan dan ketakwaan kepada Allah Swt, ketika mengalami stres dan depresi (banyak faktor penyebabnya) akan cenderung mudah terpengaruh dan terbawa pada kehidupan bebas dan menyimpang dari aturan dan ajaran agama. Kehidupan hura-hura, hedonisme sebebas-bebasnya sampai kepada kehidupan malam, alkohol, narkoba dan seks bebas.

Pengaruh media cetak maupun elektronik yang menyimpang dapat mempengaruhi orientasi seks pada anak. Pada awalnya anak hanya iseng membaca atau menonton hathal yang berbau porno (kegiatan seks para laki-laki homo atau kegiatan seks perempuan lesbian), lambat laun akan muncul perasaan hobi dan menyenangi kegiatan membaca atau menonton kegiatan seks homo atau lesbi, maka lambat laun ada keinginan mencoba dan mencari pasangan.

Trend dan gaya homoseksual pada zaman ini bukan hanya sekedar ikut-ikutan saja, akan tetapi sudah berorientasi pada rasa solider dan toleransi terhadap teman, sehingga ikut masuk dalam keanggotaan atau komunitas homoseksual. Disamping itu kebutuhan akan pekerjaan (yang biasanya dilakukan oleh perempuan salon, panti pijat) menyebabkan seorang laki-laki normal terjerumus pada pergaulan homoseksual dalam lingkungan pekerjaannya. 
Beberapa teori diungkapkan tentang etiologi atau penyebab dari munculnya seorang waria. Beberapa ahli mengungkapkan pada penyebab biologis dan penyebab secara genetik, Sedangkan ahli yang lain mengungkapkan disebabkan oleh proses belajar sosial dan disfungsi dari peran keluarga (Ellis, 2002). Terbentuknya seseorang menjadi waria tidak lepas dari proses belajar ketika masih dalam perawatan (pola asuh) orang tua. Peran keluarga dalam bidang kesehatan dan dukungan sosial berkontribusi bagi balita dalam menjalani proses tumbuh kembang secara normal dan wajar sehingga tidak ada penyimpangan. (Suryanto, 2014). Pola asuh orang tua dapat mempengaruhi pembentukan karakter anak. Interaksi anak dan orang tua pada awal kehidupan penting sebagai dasar perkembangan emosional anak Pengasuhan yang keras dapat meningkatkan frekuensi kejadian gangguan prilaku pada anak (Puspita Sari, 2014). Dengan kata lain keluarga merupakan lingkungan pertama dan utama bagi perkembangan anak. Pola asuh keluarga mempengaruhi proses sosialisasi (Indarjo, 2009). ${ }^{1}$

Ayah mempunyai pengaruh besar dalam perkembangan peran seksual anak. Jika peran ayah kecil atau tidak berperan sama sekali dalam perkembangan anak, terutama dalam hal pola asuh, maka akan muncul kesimpangsiuran peran jenis kelamin anak.

Menurut Kartini ${ }^{3}$, sebab-sebab perilaku homoseksual, antara lain:

1. Faktor dalam berupa ketidakseimbangan hormon-hormon seks di dalam tubuh seseorang.

2. Pengaruh lingkungan yang tidak baik atau tidak menguntungkan bagi perkembangan kematangan seksual yang normal.

3. Seseorang selalu mencari kepuasan relasi homoseksual karena pernah menghayati pengalaman homoseksual yang menggairahkan pada masa remaja.

4. Seorang anak laki-laki pernah mengalami pengalaman traumatis dengan ibunya sehingga timbul kebencian atau antipati terhadap ibunya dan semua wanita.

Menurut Kartono ${ }^{4}$, penjara dan asrama-asrama putra, tempat para pemuda dan kaum pria berdiam terpisah dengan kaum wanita, banyak menghasilkan peristiwa homoseksual. Kedekatan, perasaan saling membutuhkan untuk mengerjakan tugas, berbagai aktivitas asrama dilakukan bersama-sama, saling melihat organ seks, saling melindungi dan memberikan rasa aman dapat menjadi sebab tumbuh dan berkembangnya benih-benih homoseksual dikalangan pelajar dan remaja di asrama-asrama putra.

Menurut Adelsa (2009), faktor lingkungan keluarga yang dapat memengaruhi terbentuknya homoseksual, yaitu: (1) pola asuh, dan (2) figur orang yang berjenis kelamin sama dan relasinya dengan lawan jenis. Pemicu seseorang individu menjadi homoseksual dibagi menjadi 3 hal yaitu yang pertama precipating event yaitu pemicu awal seseorang menjadi homoseksual. Pemicu awalnya adalah traumatis yaitu peristiwa disodomi waktu kecil, pernah ditolak wanita yang dicintainya, pernah disakiti oleh wanita yang dicintainya, yang semuanya itu menjadi ketraumaan subyek dan akhirnya memutuskan untuk memilih

${ }^{1}$ Dewi Rokhmah, Pola Asub dan Pembentukan Perilaku Seksual Berisiko terhadap HIVI AIDS Pada Waria. (Jurnal Kesehatan Masyarakat. KEMAS 11 (1) (2015) 125-134, 2015), hlm. 126.

2 Dagun Save M, Psikologi Keluarga: Peranan Ayah Dalam Keuarga, (Jakarta: Rhineka Cipta. 1990), hlm. 104-105.

${ }^{3}$ Kartini Kartono, Op. Cit, hlm. 248.

${ }^{4}$ Ibid, hlm. 248. 
kehidupan homoseksual. Pemicu kedua yaitu conditioning event yaitu faktor penguat yang menyebabkan seseorang mempunyai kecenderungan homoseksual menjadi lebih merasa didukung dan terkondisikan dengan keadaan homoseksual. ${ }^{1}$

Penyebab perilaku homoseksual, selain dari pola asuh yang salah dari orang tua, yaitu adanya dominasi figur salah satu orang tua yang sama dengannya. Misalnya orang tua yang berstatus single parent (ayah atau ibu saja) dapat menyebabkan anaknya memiliki sifat dan karakter seperti ayah atau ibu. Seorang anak perempuan yang diasuh dan dibesarkan oleh ayahnya maka ketika ia tumbuh besar akan cenderung memiliki sifat dan kepribadian seorang laki-laki. Begitupun sebaliknya bilamana seorang anak lakilaki yang diasuh dan dibesarkan oleh seorang ibu, maka ia akan cenderung memiliki sifat dan kepribadian seorang perempuan. Selanjutnya, bila anak yang telah memiliki kecenderungan homoseksual, maka konsisi dan lingkungan pergaulan dapat menjadi penguat dan pendorong tumbuh kembang sifat dan kepribadian homoseksual.

Faktor penguat ini berasal dari lingkungan yang terdiri dari orang tua yang memperlakukan anaknya seperti wanita, memperbolehkan anak lakilakinya mengambil jurusan seni tari yang dimana itu identik dengan kondisi wanita. Orang tua juga tidak mengetahui bahwa seoranganaknya seorang homoseksual sehingga anak tersebut merasa bebas karena tidak ada yang menghukum atas pilihan hidupnya menjadi homoseksual. Lingkungan kawan juga menjadi penguat kondisi homoseksual subyek sering bergaul dengan kawan-kawan yang homoseksual sehingga menyebabkan terpengaruh dan memilih menjadi homoseksual. Faktor pemicu ketiga yaitu consequensy event pada diri mahasiswa homoseksual yang dapat dilihat dari faktor kenyamanan pada kondisi homoseksual. subyek penelitian lebih merasa bahwa kondisi homoseksual adalah pilihan hidup. ${ }^{2}$

Menurut Freud ${ }^{3}$ pada dasarnya individu sudah memiliki potensi sejak lahir untuk menjadi homoseksual dan heteroseksual. Terjadinya orientasi seks homoseksual, heteroseksual, ataupun biseksual tersebut dipengaruhi oleh lingkungan, khususnya lingkungan masa kecinya bersama kedua orangtuanya. Selanjutnya menurut Hosea Handoyo ${ }^{4}$ bahwa orientasi seksual merupakan variasi yang terjadi dalam perkembangan seksual individu yang akan berkembang sesuai dengan kondisi lingkungan sehingga homoseksual bukanlah suatu penyakit. Seorang lakilaki dapat menjadi seorang gay bila memiliki hubungan yang terlalu dekat dengan ibunya atau karena kurang dan hilangnya figur kebapakan dalam keluarga, sehingga bapak yang terlalu disiplin yang pada perkembangan selanjutnya memunculkan kebencian pada lakilaki secara umum. Hal ini berlaku terbalik pada kasus perempuan lesbian dimana posisi ibu hilang atau terlalu disiplin dan ayah yang terlalu dekat dengan anak perempuannya. Sebagian besar psikolog dan psikiatri percaya bahwa hal ini adalah "penyebab" utama homoseksualitas yang baru kemudian mengubah proses biologis dalam tubuh.

1 Sari Nur Azizah, Konsep Diri Homoseksual di Kalangan Mahasiswa di Kota Semarang: Studi Kasus Mahasiswa Homoseksual di Kawasan Simpanglima Semarang, Journal Of Non Formal Education and Community Empowement. ENFECE 2 (2) (2013), hlm. 42.

${ }^{2}$ Ibid., hlm. 42

${ }^{3}$ Deni Noviantoro, Rasionalisasi Nilai-Nilai Agama dan Konstruksi Seksualitas Individu Gay. (Yogyakarta: Fakultas Ushuludin dan Pemikiran Islam UIN Sunan Kalijaga. (Skripsi). 2015), hlm.13.

${ }^{4}$ Ibid., hlm. 14. 
Faktor lain yang menyebabkan seseorang menjadi homoseksual adalah faktor biologis (kelainan otak dan syaraf) serta faktor psikodinamika yaitu adanya gangguan perkembangan seksual sejak kecil atau masa kanak-kanak. ${ }^{1}$ Selanjutnya faktor sosiokultural yaitu adanya adat istiadat yang memberlakukan hubungan homoseksual dengan alasan yang tidak benar dan faktor lingkungan, dimana dimungkinkan dan mendorong hubungan para lelaki homoseksual menjadi erat. $^{2}$ Perlakuan masyarakat yang tidak dapat menerima kehadiran homoseksual dan pandangan agama dan moral yang melarang homoseksual mengakibatkan mereka hidup tersisih, terkucil dari masyarakat, dijauhi oleh keluarga, teman, lingkungan kerja serta masyarakat menjadi penyebab sulitnya terapi homoseksual. ${ }^{3}$

Pengaruh prilaku teman, keluarga, dan masyarakat yang seringkali menjauhi orangorang homoseksual menyebabkan mereka hidup tersisih dalam pergaulan masyarakat dan membuat orang-orang homoseksual semakin terjerumus pada kehidupan seks yang menyimpang.

\section{DAMPAK PERILAKU SEKSUAL}

Dari jaman ke jaman perilaku homoseksual selalu hidup dengan gaya tersendiri utamanya yang berkaitan perilaku seks. Kehiduan kaum homo tidak terlepas dengan dunia seks, dengan pasangan tetap ataupun seringkali berganti-ganti. Orientasi seks bagi kaum homo sama halnya dengan kehidupan orang-orang normal pada umumnya. Ada yang menjalani kehidupan sebagai homo untuk mencari kehidupan yang tenang bersama pasangan tetapnya dan ada juga berorientasi untuk mencari kepuasan dengan mengumbar syahwatnya dengan berganti-ganti pasangan.

Seorang homoseksual senantiasa berhadapan dengan adanya realitas gaya hidup tertentu yang berlaku di kalangan kaum homoseksual. Gaya hidup ini meliputi cara, perilaku, dan kebiasaan tertentu baik itu dalam mengekspresikan orientasi seksual, bersosialisasi, maupun menjalani hidup sehari-hari. Penelitian mengenai homoseksual pria menunjukkan bahwa lebih dari $75 \%$ pria homoseksual mengaku telah melakukan hubungan seksual bersama lebih dari 100 pria berbeda sepanjang hidup mereka: sekitar 15\% dari mereka pernah mempunyai 100-249 pasangan seks, 17\% mengklaim pernah mempunyai 250-499, 15\% pernah mempunyai 500-999, dan 28\% mengatakan pernah berhubungan dengan lebih dari 1000 orang dalam hidup mereka. (Bell AP, Weinberg MS. Homosexualities. New York 1978).

Dari hasil penelitian di atas, dapat diketahui bahwa kaum homo ratarata pernah dan sering melakukan hubungan seksual, baik dengan pasangan tetap atau tidak tetap. Gaya hidup dengan orientasi homoseksual beresiko penyakit serius, apalagi dengan seringnya berganti-ganti pasangan. Gaya seks seperti ini tentu saja akan berpengaruh signifikan pada kesehatan kaum homo.

${ }_{1}$ Rama Azhari dan Putra Kencana, Membongkar Rahasia Jaringan Cinta Terlarang Kaum Homoseksual, (Jakarta: Hujjah Press. 2008), hlm.51.

${ }^{2}$ Ibid., hlm. 51

${ }^{3}$ Maya Fransisca, Gambaran Psychological Well Being Pada Pria Gay Dewasa Muda Yang Telab Coming Out. (Jakarta: Skripsi. Fpsi UI 2009). hlm. 1.

${ }^{4}$ Veronica Adesla, Resiko yang Rentan Dihadapi Oleh Homoseksual. http://www.psychoshare.com/file522/psikologi-klinis/resiko-yang-rentan-dihadapi-oleh-homosek sual.html. Diposkan tanggal 28 April 2014. 
Gaya hidup tertentu pada kaum homoseksual dapat beresiko buruk terhadap kesehatan fisik maupun mental \& emosional, seperti: berganti-ganti pasangan dalam berhubungan seksual (berhubungan intim); melakukan hubungan seksual yang tidak aman (tidak menggunakan kondom); melakukan anal sex, minum-minuman keras \& narkoba. ${ }^{1}$

Igartua (2009) mengatakan bahwa homoseksual dan biseksual mempunyai dampak yang lebih besar terhadap permasalahan kesehatan, baik secara phisik ataupun secara mental. Perilaku seksual homoseksual dan biseksual bukan hanya mengikat dan menyebabkan diri seseorang pada bahaya perilaku seksual, tetapi dapat juga diikuti oleh alkohol dan penyalahgunaan obat. Temuan tersebut juga didukung oleh Noell \& Ochs (2001), yang mendeskripsikan negatif orientasi seksual (homoseksual dan biseksual) mempunyai kecenderungan untuk menggunakan rokok, alkohol, penyalahgunaan obat, atau bahkan mengalami depresi dan melakukan bunuh diri dibandingkan dengan individu dengan orientasi seksual yang wajar.

Lebih jauh, Maguen (2000) menemukan bahwa individu homoseksual dan biseksual telah memiliki tendensi yang tinggi untuk terjangkit HIV. Sutmoller dkk (2002) juga menjelaskan bahwa homoseksual dapat menimbulkan kecenderungan yang tinggi untuk menderita penyakit seperti syphilis dan hepatitis B, dan kedua penyakit tersebut dapat menjadi prediktor bagi seseorang untuk terjangkit HIV. Selanjutnya menurut Maguen dkk (2000) perilaku seksual homoseksual dilakukan dengan anal seks atau vagina seks tanpa pengaman, sehingga membuat kesehatan mereka menjadi beresiko dan berbahaya. ${ }^{3}$

Gaya hidup seksual para waria tercermin dalam melakukan aktifitas seksualnya, seperti : bergonta-ganti pasangan, tidak menggunakan kondom serta melakukan seks anal dan oral. Hal ini menyebabkan kehidupan waria sangat rentan dan beresiko dengan terjadinya kekerasan psikologis dan seksual yang berdampak terhadap kemungkinan penularan dan penyebaran penyakit IMS dan HIV/ AIDS. Selama dasawarsa terakhir, prevalensi IMS, terutama infeksi HIV, pada komunitas waria dilaporkan meningkat secara bermakna. Di Jakarta, hasil survey Seroprevalens pada pertengahan tahun 2002 terhadap 241 waria PSK menunjukkan prevalensi HIV dan early syphilis mencapai $22 \%$ dan 19,3\%. Hal ini merupakan suatu peningkatan yang bermakna jika dibandingkan dengan survey waria di Jakarta pada Juli 1995, yang hanya menemukan prevalensi HIV seropositif sebesar 7,9\%. Data terbaru berdasarkan hasil Surveilans Terpadu Biologis Perilaku (STBP) pada kelompok beresiko tinggi di Indonesia pada tahun 2007 menunjukkan bahwa angka prevalensi HIV dan Infeksi Menular Seksual (IMS) pada waria sangat tinggi di tiga kota, yaitu 14\% di Bandung, 25,2\% di Surabaya, dan 34\% di Jakarta. Berdasarkan data estimasi Dinas Kesehatan Propinsi Jawa tengah, di Jawa Tengah pada tahun 2006 dilaporkan bahwa sebanyak 830 dari total 1058 waria terindikasi virus HIV. Dari jumlah tersebut 228 waria diantaranya positif mengidap virus HIV. Salah satu penyebab waria mudah terserang HIV/ AIDS karena kehidupan seks para waria yang menyimpang. Sementara di Kota Semarang,

\footnotetext{
1 Ibid.

Alhamdu, Orientasi Seksual : Faktor, Pandangan Kesehatan dan Agama. https: / / www.google.co.id/?gws $\mathrm{rd}=\mathrm{ssl} \# \mathrm{q}=$ dampak+homoseksual+pada + kesehatan + jurnal.

3 Ibid., hlm.17.
} 
berdasarkan data estimasi pada tahun 2006 diketahui dari 221 waria tercatat 27 orang telah mengidap HIV (STBP, 2007). ${ }^{1}$

Dari beberapa pendapat di atas, sangat jelas bahwa perilaku homoseksual sangat berpengaruh tidak baik pada kesehatan fisik, bagian mulut, alat kelamin, atau tempat pembuangan kotoran (anus), walaupun menggunakan alat pengaman, seperti kondom. Kuman, virus atau bakteri dapat masuk ke dalam mulut dengan oral seks, bahkan dapat menimbulkan peradangan mulut atau yang terparah adalah kanker mulut. Selanjutnya pada bagian alat kelamin (penis) akan menularkan penyakit kelamin menular HIV, syphilis, hepatiis B atau penyakit kelamin lainnya. Pada bagian anus akan terjadi peradangan dan bahkan kerusakan bagian anus.

Menurut Veronica ${ }^{2}$ setelah menganalisa sekitar 25 penelitian terdahulu mengenai orientasi seksual dan kesehatan mental, para peneliti mengatakan dalam sebuah jurnal medis BMC Psychiatry bahwa resiko bunuh diri dapat melambung hingga $200 \%$ jika seseorang terlibat dalam gaya hidup homoseksual. Data-data penelitian yang dilakukan oleh berbagai sumber diatas membenarkan adanya resiko gangguan kesehatan mental dan emosional pada homoseksual, seperti: depresi, gangguan mental, gangguan kecemasan, gangguan perilaku (melakukan penganiayaan-kekerasan seksual atau fisik /sexual or physical abuse), menyakiti / melukai diri sendiri, hingga perilaku bunuh diri.

Selain menyebabkan resiko buruk pada kesehatan fisik, homoseksual juga dapat beresiko buruk pada kesehatan mental atau psikis. Mereka akan seringkali mengalami kondisi mental tertekan, stres dan bahkan depresi, karena perilaku seks yang menyimpang, yang jelas saja pasti ada keinginan orang-orang homoseksual untuk membina keluarga bahagia dan mempunyai anak sebagai penyambung generasi mereka yang akan datang, sebagaimana kehidupan orang pada umumnya. Selain itu, seks bebas dan menyimpang kaum homo tidak diterima dengan baik, baik oleh agama, moral dan adat istiadat. Bahkan teman, keluarga dan masyarakat akan menjauhi mereka dan menyebabkan mereka hidup tersisih dan menyendiri dari masyarakat, keluarga dan teman.

Dampak secara psikis yang dialami pelaku homoseksual adalah hinaan, makian hingga kekerasan fisik yang seringkali disertai dengan pengrusakan harta benda mereka. Kondisi tersebut menjadi permasalahan utama bagi kaum homoseksual. Mereka merasakan bahwa posisi mereka adalah kaum minoritas, dalam kondisi tertekan seperti itu dapat menimbulkan kecemasan sosial (social anxiety) pada kaum homoseksual. Mereka merasa ketakutan ditolak dan didiskriminasi. ${ }^{3}$

Selain diskriminai verbal, tidak jarang kaum homoseksual juga mendapatkan diskriminasi secara sosial seperti di bulli bahkan dikucilkan dan hal ini senada dengan hasil penelitian yang dilakukan Herek dengan 165 mahasiswa sebagai subjeknya di universitas Yale, menemukan bahwa kebanyakan diskriminasi yang dialami kaum gay selain serangan

\footnotetext{
${ }^{1}$ Dewi Rokhmah, Op.Cit. hlm. 126-127.

${ }^{2}$ Veronica Adesla, 2014. Resiko yang Rentan Dihadapi Oleh Homoseksual.
} http://www.psychoshare.com/file-522/psikologi-klinis/resiko-yang-rentan-dihadapi-oleh-homosek_sual.html. Diposkan tanggal 28 April 2014.

${ }^{3}$ Endof Pudan Sembiring, dkk. Implementasi Perda No. 14 Tabun 2008 Tentang Penanggulangan HIV Dan Aids Di Kabupaen Malang: Studi Tentang Peran Komunikasi Dalam Implementasi Kebijakan Publik, (Jurnal Adminstrasi Publik (Jap), Vol. 1, No. 3, 2013), hlm. 184. 
verbal juga kerap mereka diasingkan dari kelompok sosial (54\%). ${ }^{1}$ Hal ini juga senada dengan hasil studi yang dilakukan oleh D’Augelli \& Herschberger (1993), Remafedi(1987), dimana pengasingan yang diterima kaum homoseksual oleh kelompok sosial tergambar dari sedikitnya 46\% pemuda-pemuda gay dan lesbian dengan resiko kehilangan teman setelah membeberkan orientasi seksual mereka. ${ }^{2}$ Menurut Lewis ${ }^{3}$ bahwa perlakuan diskriminasi inilah yang sebenarnya yang menjadi sumber stress bagi kaum gay sehingga mereka mengalami psychological distress yang tinggi. Stress sendiri didefinisikan sebagai sebuah keadaan yang dialami ketika ada sebuah ketidaksesuaian antara tuntutan-tuntutan yang diterima dan kemampuan untuk mengatasinya. Stress adalah ketidakseimbangan antara bagaimana kita memandang tuntutan-tuntutatn dan bagaimana kita berpikir bahwa kita dapat mengatasi semua tuntutan yang menentukan apakah kita dapat merasakan stress, merasakan distress atau eustres.

Psychological distres yang tinggi yang dialami oleh kaum gay mengakibatkan mereka memiliki tingkat penerimaan yang rendah. Selain penerimaan dan penilaian dari masyarakat, faktor keluarga memiliki peranan yang besar yang kerap dihadapi gay. Orang tua yang mengetahui anaknya adalah seorang homoseksual seringkali merasa terpukul dan merasa bersalah, tidak jarang orang tua akan menghetikan bantuan finansial, mengusir anak dari rumah atau mengucilkan anaknya. ${ }^{4}$

Kondisi yang dirasakan kaum gay akibat diskriminasi sosial adalah dilema ketika dihadapkan kepada lingkungan mengenai eksistensi mereka di dalam masyarakat, dorongan homoseksual yang dirasakannya menyebabkan merasa cemas, disukai dan sedih. Konflik psikis tersebut menyebabkan perasaan bersalah, malu, cmas serta perasaan tertekan atau depresi. Umumnya individu homoseksual adalah individu yang merasa takut, bersalah, tidak dapat menerima dirinya sebagai seorang homoseksual dan berpura-pura sebagai seorang yang heteroseksual. ${ }^{5}$

Diskriminasi keberadaan kaum homoseksual sendiri selain dari masyarakat secara budaya juga tesandung oleh masalah larangan agama dimana masyarakat Indonesia dengan nilai-nilai ketimurannya menganggap bahwa hubungan sesama jenis adalah tabu dan terlarang. Setiap agama di Indonesia memiliki pandangan tersendiri terhadap homoseksual. Dalam agama Islam dan Kristen terdapat larangan yang jelas tentang adanya hubungan antar sesama jenis (gay, lesbian, dan waria) ${ }^{6}$

Larangan terhadap aktivitas kaum gay, tidak hanya diatur oleh agama, tetapi juga hukum negara. Salah satu hukum negara yang melarang adanya kaum gay yaitu UU Pornografi pasal 5 ayat 3, intinya melarang tindakan seksual, penetrasi dan hubungan seks pada pasangan sejenis, anak-anak, orang meninggal, dan hewan. Tidak ada sanksi tegas terhadap perilaku kaum gay, sehingga kaum gay muncul dan memperlihatkan identitasnya

1 Darwin Tambunan. Perbedaan Kesehatan Mental Pada Gay Ditinjau dari Perilaku Religius, (Fakultas Psikologi Universitas Sumatera Utara. Skrpsi. 2010), hlm. 11.

2 Johan Candra, Pemaknaan Hidup Seorang Homoseksual, (Fakultas Psikologi Universitas Sumatera Utara. Skripsi. 2008), hlm. 11.

${ }^{3}$ Darwin Tambunan. Op.Cit. hlm. 12.

${ }^{4}$ Maya Fransisca, Op. Cit. hlm. 3.

${ }^{5}$ Matheus Antonius Parlaungan. Gambaran Kesepian Pada Gay Di Kota Medan. (Fakultas Psikologi Universitas Sumatera Utara. Skripsi. 2008), hlm. 3.

${ }^{6}$ Darwin Tambunan, Op.Cit. hlm. 14. 
ke publik. Akibatnya aktivitas gay yang terlarang itu tetap berlangsung. Hal ini merupakan suatu pertanda bahwa larangan tersebut hanya sebatas Undang-Undang. Selain itu dalam Undang-Undang No. 44/2008 tentang pornografi, homoseksualitas masuk dalam kategori perilaku seks menyimpang. ${ }^{1}$

Fakta-fakta tentang penolakan keberadaan kaum homoseksual kerap menjadi salah satu resiko yang harus dihadapi oleh kaum gay, dan tidak jarang penolakan tersebut membuat kaum gay rentan menimbulkan stres yang membuat gay secara individu harus memiliki kemampuan untuk menangani permasalahannya dengan melakukan usaha untuk mengurangi situasi penuh stres. Merespon situasi yang penuh stres merupakan konsep strategi coping. Strategi coping adalah suatu tindakan merubah kognitif dan perilaku secara terus menerus untuk mengatasi tuntutan eksternal dan internal yang dinilai membebani atau melebihi sumber daya yang dimiliki individu lebih lanjut dijelaskan bahwa coping adalah upaya mengurangi atau mentoleransi beban perasaan yang tercipta karena stres. Setiap individu memberikan respon berbeda terhadap permasalahan yang dialaminya sehingga salah satu faktor yang mempengaruhi coping adalah kepribadian individu sendiri.

\section{CARA MENGATASI HOMOSEKSUAL}

Pada lingkungan kebudayaan yang relatif modern, keberadaan kaum homo seksual masih ditolak oleh sebagian besar masyarakat sehingga eksistensinya berkembang secara sembunyi-sembunyi. Gadpaille (1989) menyatakan bahwa pada masa sekarang masyarakat modern cenderung bersikap negatif terhadap aktivitas erotik antar sesama jenis kelamin. Pandangan negatif mengenai homo seksual inilah yang menyebabkan homo seksual cenderung tidak diterima masyarakat, rentan mengalami diskriminasi, cemoohan serta sanksi-sanksi sosial lainnya (Ary, 1987: 9). Sejumlah keberatan terhadap perilaku homo seksual sebagian besar adalah karena alasan keagamaan.

Lenhne (1976) mencetuskan istilah bomophobia untuk menggambarkan kekuatan irasional dan intoleransi terhadap homoseksual. Seorang individu yang diketahui sebagai pria homoseksual atau gay beresiko untuk mengalami diskriminasi dalam pekerjaan dan kehidupan sosialnya (Chumairoh, 2008: 5). Sanksi sosial yang diberikanmasyarakat pada umumnya beragam, mulai dari cemoohan, penganiayaan, hingga hukuman mati seperti yang pernah terjadi pada negara-negara di barat. Penolakan serta diskriminasi masyarakat terhadap kaum homoseksual yang berupa tuntutan untuk menjadi heteroseksual dalam seluruh aspek kehidupan melatarbelakangi keputusan sebagian kaum homo seksual untuk tetap menyembunyikan keadaan orientasi seksualnya dari masyarakat sehingga orang-orang yang memiliki orientasi homoseksual memilih untuk menutupi orientasi seksualnya baiksecara sosial, adat dan hukum. ${ }^{2}$

Pada umumnya pelaku homoseksual menyembunyikan tentang orientasi seksual dihadapan umum. Mereka menyadari bahwa perilaku homoseksualnya tidak diterima dalam kehidupan masyarakat, akibat dari itu seringkali mereka mendapat perlakuan diskriminasi dari masyarakat, keluargapun akan mengalami stres akan perilakunya itu, dan banyak teman-

${ }^{1}$ Laily Anggraini. Hubungan Antara Kepribadian Otoritarian Dengan Sikap Nilai dan Perilaku Diskriminasi Terhadap Homoseksual, (Jurnal Ilmiah Mahasiswa Universitas Surabaya Vol. 2 No. 1. 2013), hlm. 4.

2Shinstya Kristina, Informasi dan Homoseksual - Gay (Studi Etnometodologi Mengenai Informsi Gay Pada Komunitas Gaya Nusantara Surabaya). journal.unair.ac.id/download-fullpapers-jurnal\%20shinstya.doc 
teman yang mulai menjauhinya satu persatu. Pada akhirnya pelaku homoseksual akan mengalami tekanan kejiwaan, stres dan depresi.

Peyimpangan seksual yang dilakukan oleh kaum homoseksual secepat mungkin harus segera ditangani dan tdk boleh dibiarkan. Tujuan penanganan terhadap penyimpangan homoseksual adalah untuk mengembalikannya pada kehidupan seks yang normal. Penanganan dapat dilakukan oleh ahli psikolog maupun pendekatan secara keagamaan. Pendekatan yang dilakukan oleh psokolog biasanya berupa terapi kejiwaan yang berusaha mengembalikan kesadaran dan perasaan seorang homoseksual akan jati dirinya sesungguhnya dan masa depannya yang akan datang. Sedangkan pendekatan agama adalah menyadarkan dirinya akan perilaku homoseksual yang dilarang oleh agama, dikutuk oleh AllahSwt, dan berbagai akibat yang akan dialami, baik dari sisi kesehatan, hubungansosialnya, depresi dan stres dan hilangnya masa depan bersama keluarga yang sakinah, mawaddah, dan warrahmah.

Ada beberapa cara yang ditempuh oleh para konselor atau psikolog untuk mengembalikan seorang homoseksual menjadi individu yang normal, yaitu a) Self mengacu kepada diri seseorang yang berkaitan dengan seluruh identitas yang ada pada dirinya, contoh konkritnya adalah nama, alamat, nama orangtua, lingkungan keluarga dan pengaruhnya terhadap konseli dan aspek-aspek lain yang berkaitan dengan konseli. Melalui self ini bagaimana konseli mampu menyadari identitas asli diri mereka dengan segala aspek bawaan yang ada pada dirinya. b) Relationship mengacu pada diri seseorang untuk mampu memahami setiap hubungan yang ia jalin dan merujuk pada hubungan sosial. Hubungan sosial ini berkaitan dengan kisaran jumlah teman laki-laki dan perempuan, bagaimana hubungan konseli dengan teman-teman dekatnya, dan berkaitan dengan karakteristik teman-teman dan lingkungan yang menjadi tempat untuk berhubungan secara sosial. ${ }^{1} \mathrm{c}$ ) Differential of feeling yaitu mengidentifikasian konseli terhadap perbedaan perasaan terhadap teman-teman dan lingkungan sekitar. Aspek perasaan atau afektif berkaitan dengan beberapa hal, seperti gender dan problematika yang menyertainya, bagaimana perasaan konseli terhadap teman-teman dekatnya, baik dengan lawan jenis maupun dengan teman sejenis, eksplorasi masalah yang berkaitan dengan perasaan yang menyertai konseli dan pemberian sebuah label terhadap konseli dengan berbagai pertimbangan yang mengacu pada perasaan. d) Identify yaitu mengacu pada identitas baru yang melekat pada diri konseli/klien (pelaku homoeksual) dimana konseli diajak mengkonstruk kembali pikiran, perasaan, dan tindakan. Identifikasi diri ini akan menghasilkan sebuah deklarasi pribadi bahwa konseli telah mengaku sebagai orang yang normal atau menjadi seorang yang lesbian, gay, biseksual, atau transgender. Jika konseli tetap teridentifikasi sebagai lesbian, gay, biseksual atau transgender maka selanjutnya masuk pada kontinum spritual. e) Spiritual Intervensi adalah upaya konselor/psikolog untuk memberikan kesadaran kepada konseli dalam perspektif agama. f) Acceptane of environtmental yaitu penerimaan diri terhadap lingkungan mengacu pada masalah-masalah yang mungkin dihadapi konseli dalam proses penyesuaian diri terhadap lingkungan barunya. ${ }^{2}$

${ }^{1}$ Khilman Rofi Azmi, Enam Kontinum Dalam Konseling Transgender Sebagai Alternatif Solusi Untuk Konseli LBGT, (Jurnal Psikologi Pendidikan dan Konseling Volume 1 Nomor 1 Juni 2015), hlm. 53

2 Ibid., hlm. 54 
Usaha yang dilakukan oleh psikolog juga harus diiringi dengan motivasi dalam diri pelaku homoseksual, sehingga orientasi seksualnya dapat kembali normal. Disamping itu perlu juga adanya dukungan dari keluarga dan masyarakat lingkungan sekitarnya. Diskriminasi dan berbagai penolakan dari teman, keluarga, dan masyarakat justru akan menambah terpuruknya pelaku dalam kehidupan yang menyimpang dari agama, moral masyarakat dan adat istiadat.

Respon yang ditunjukkan orangtua terhadap pengungkapan diri yang dilakukan oleh anaknya yang gay, dapat berupa penerimaan ataupun penolakan. Menurut Wong dan Tang (2004) penerimaan dan penolakan yang dilakukan oleh orangtua terhadap orientasi seksual anaknya, merupakan sebuah proses penyesuaian diri yang berkesinambungan. Penyesuaian diri dijelaskan oleh Schneiders (1964) sebagai proses yang meliputi respon mental dan perilaku ketika individu berusaha untuk mengatasi ketegangan, rasa frustasi, kebutuhan, konflik yang asalnya dari dalam dirinya sendiri dan kemudian menghasilkan derajat kesesuaian antara tuntutan yang berasal dari dalam diri individu dengan dunia tempat individu itu hidup. ${ }^{1}$

Semua informan memiliki keinginan yang sama untuk memperbaiki diri atau membebaskan diri dari perilaku seksual menyimpang sebagai gay namun kendala utama mereka membebaskan diri adalah sikap pesimis atau kurang yakin akan hasrat mereka untuk sembuh total, bahkan ada kecenderungan mereka semakin menenggelamkan diri mereka pada kebiasaan atau perilaku menyimpang tersebut, karena hasrat dan kebutuhan biologis dan psikologis mereka terpenuhi. ${ }^{2}$

Salah satu cara menangani perilaku menyimpang adalah dengan pendekatan agama, dengan berdasarkan Al-Qur`an dan sunah. Seorang konselor dalam melakukan bimbingan harus memiliki kecerdasan spiritual dengan konseling terapi. Menurut Musfir ${ }^{3}$ Konseling terapi mempunyai keterkaitan yang kuat dengan ilmu jiwa, di dalamnya dipelajari tentang perilaku yang normal Pentingnya Kecerdasan Spiritual dalam Menangani Perilaku. (Ani Agustiyani M) ataupun perilaku menyimpang. Konseling terapi merupakan salah satu kewajiban seorang muslim kepada sesamanya.

Pentingnya kecerdasan spiritual (jiwa) dalam penyembuhan penyakit seperti perilaku menyimpang, sesuai dengan firman Allah SWT dalam surat Yunus ayat 57 yang artinya: "Hai manusia, sesunggubnya telah datang kepadamu pelajaran dari Tubanmu dan penyembuh bagi penyakit-penyakit (yang berada) dalam dada dan petunjuk serta rahmat bagi orang-orang yang beriman".

Membimbing dan membantu menyelesaikan masalah dibutuhkan kecerdasan spiritual. Di mana seorang konselor harus memiliki motivasi spiritual dengan tetap konsisten beribadah kepada Allah dan takwa. Membimbing memerlukan kecerdasan spiritual agar dapat menjadi pendidik sekaligus orang tua bagi klien, sehingga konselor mampu membimbing, membina, mendidik sesuai kaidah-kaidah spiritual religius. Seorang

\footnotetext{
${ }^{1}$ Berlian Laras dan Achmad Chusairi. Faktor Penyesuaian Diri Gay Dewasa Pada Orang Tua Pasca Pengungkapan Diri Kepada Orangtua, (Jurnal Psikologi Kepribadian dan Sosial. Vol. 2 No. 1, April 2013), hlm. 9.

2 Tommy Dwi Pranata, Perilaku dan Realitas Sosial Kebidupan Gay di Kota Semarang, (e-Journal Sosiatri-Sosiologi. 3 (3): 135-150. Volume 3, Nomor 3, 2015), hlm. 147.

3 Ani Agustiyani Maslahah, Pentingnya Kecedasan Spiritual Dalam Menangani Perilaku Menyimpang. Konseling Religi, (Jurnal Bimbingan Konseling Islam. Volume 3, Nomor 1, Januari - Juni, 2012) hlm. 30

${ }^{4}$ Ibid., h.32
} 
konselor merupakan mitra dan uswah (teladan) bagi anak didik dalam membangun sebuah karakter sehari-hari (caracter building). ${ }^{1}$

Dengan menambah kualitas dan kuantitas beribadah, baik berupa shalat, puasa, mengaji dan dzikir kepada Allah Swt, akan membantu kesembuhan bagi pelaku homoseksual. Disamping itu ada tekad dan usaha yang keras bagi pelaku seksual untuk menjauhi dan meninggalkan dunia homoseksual dan kembali pada kehidupan normal dan agamis yang diridhai oleh Allah Swt.

\section{KESIMPULAN}

1. Homoseksual berasal dari kata homo yang berarti sama dan sexual yang berarti hubungan seksual atau berhubungan dengan kelamin. Hubungan seksual adalah orang yang konsisten tertarik secara seksual, romantik, dan afektif terhadap orang yang memiliki jenis kelamin yang sama dengan mereka. Ada dua istilah terdapat pada orang yang mempunyai kecenderungan homoseksual yaitu lesbian dan gay dan istilah ini sangat terkenal di lingkungan masyarakat.

2. Penyebab faktor internal pelaku homoseksual adalah faktor bawaan dari awal pembentukan sygot atau pertemuan sel sperma dan sel telur, sampai pada saat kehamilan dan kelahiran. Anak yang lahir dengan kelainan genetik dan hormonal, selanjutnya akan tumbuh dan berkembang menjadi remaja dan dewasa berdasarkan kelainan yang dimilikinya. Misalnya anak perempuan yang lahir dengan kelainan genetik dan hormonal, maka anak perempuan bisa tumbuh dan berkembang dengan fisik dan kepribadian cenderung seperti anak laki-laki. Begitu pula sebaliknya, anak laki-laki dengan kelainan genetik dan hormonal akan tumbuh dan berkembang dengan fisik dan kepribadian yang cenderung seperti perempuan

3. Penyebab faktor eksternal homoseksual adalah adanya pengaruh lingkungan. Seseorang dengan orientasi homoseksual pada awalnya pertumbuhan dan perkembangan kepribadiannya adalah normal. Secara fisik dan psikis tumbuh dan berkembang normal. Namun karena lingkungan pergaulannya sehari-hari yang kurang baik, akhirnya dapat membentuk orientasi homoseksual, seperti sering menonton video seks homo (ada keinginan untuk merasakan), terlalu bergaul terlalu dekat dengan teman lakilaki sesama jenisnya sendiri, sering mengalami putus hubungan cinta dengan teman perempuan dan merasa nyaman berada dekat dengan teman laki-laki ketimbang perempuan, sejak kecil diberi pakaian, mainan, dan teman perempuan oleh orang tua, pernah mendapat kekerasan seksual (sodomi), dan lain-lain.

4. Akibat pelaku homoseksual akan memiliki masa depan yang rusak, jauh dari nilai-nilai agama, rentan terkena penyakit menular, HIV, Gonorhoe, Sipilis, dan Harpes kelamin, depresi, alkoholik, narkoba, sanksi agama, sanksi moral dan istiadat masyarakat.

5. Terapi pelaku homoseksual dilakukan dengan pendekatan psikologis yaitu terapi kejiwaan yang berusaha mengembalikan kesadaran dan perasaan seorang homoseksual akan jati dirinya sesungguhnya dan masa depannya yang akan datang, yaitu dengan Self, Relationship, Differential of feeling, Identify, Spiritual Intervensi, dan Acceptane of environtmental.

${ }^{1}$ Ibid., hlm. 32. 
6. Terapi dengan pendekatan agama adalah menyadarkan dirinya akan perilaku homoseksual yang dilarang oleh agama, dikutuk oleh Allah Swt, dan berbagai akibat yang akan dialami, baik dari sisi kesehatan, hubungan sosial, depresi dan stres dan hilangnya masa depan bersama keluarga yang sakinah, mawaddah, dan warrahmah.

\section{REFRENSI}

Ani Agustiyani Maslahah. 2012. Pentingnya Kecerdasan Spiritual Dalam Menangani Perilaku Menyimpang. Konseling Religi. Jurnal Bimbingan Konseling Islam. Volume 3, Nomor 1, Januari - Juni 2012

Aput Hartono, 2009. Faktor Resiko Kejadian Penyakit Menular Seksual (PMS) Pada Komunitas Gay Mitra Strategis Perkumpulan Keluarga BerencanaIndonesia (PKBI) Yogyakarta. Surakarta: Fakultas Kesehatan Masyarakat Universitas Muhammadiyah Surakarta. (Skripsi).

Berlian Laras dan Achmad Chusairi. 2013. Faktor Penyesuaian Diri Gay Dewasa Pada Orang Tua Pasca Pengungkapan Diri Kepada Orangtua. Jurnal Psikologi Kepribadian dan Sosial. Vol. 2 No. 1, April 2013.

Dagun Save M, 1990. Psikologi Keluarga: Peranan Ayah Dalam Keluarga. Jakarta: Rhineka Cipta.

Darwin Tambunan. 2010. Perbedaan Kesehatan Mental Pada Gay Ditinjau dari Perilaku Religius. Skrpsi. Fakultas Psikologi Universitas Sumatera Utara. 2010.

Dewi Rokhmah, 2015. Pola Asub dan Pembentukan Perilaku Seksual Berisiko terhadap HIVI AIDS Pada Waria. Jurnal Kesehatan Masyarakat. KEMAS 11 (1) (2015) 125-134,

Deni Noviantoro, 2015. Rasionalisasi Nilai-Nilai Agama dan Konstruksi Seksualitas Individu Gay. Yogyakarta: Fakultas Ushuludin dan Pemikiran Islam UIN Sunan Kalijaga.

Dede Oetomo, 2001. Memberi Suara Pada yang Bisu. Yogyakarta: Galang Press.

Endof Pudan Sembiring, dkk. 2013. Implementasi Perda No. 14 Tahun 2008 Tentang Penanggulangan HIV Dan Aids Di Kabupaen Malang. (Studi Tentang Peran Komunikasi Dalam Implementasi Kebijakan Publik) Jurnal Adminstrasi Publik (Jap), Vol. 1, No. 3, 2013.

Johan Candra. 2008. Pemaknaan Hidup Seorang Homoseksual. Skripsi. Fakultas Psikologi Universitas Sumatera Utara.

Kartini Kartono, 1989. Psikologi Abnormal dan Abnormalitas Seksual. Bandung: CV. Mandar Maju

Khilman Rofi Azmi, 2015. Enam Kontinum Dalam Konseling Transgender Sebagai Alternatif Solusi Untuk. Konseli LBGT. Jurnal Psikologi Pendidikan dan Konseling Volume 1 Nomor 1 Juni 2015.

Maya Fransisca. 2009. Gambaran Psychological Well Being Pada Pria Gay Dewasa Muda Yang Telah Coming Out. Skripsi. Fpsi UI.

Matheus Antonius Parlaungan. 2008. Gambaran Kesepian Pada Gay Di Kota Medan. Skripsi. Fakultas Psikologi Universitas Sumatera Utara

Putu Hening Wedanthi dan I. G. A. Diah Fridari. 2014. Dinamika Kesetiaan Pada Kaum Gay. Jurnal Psikologi Udayana. Vol. 1, No. 2, 363-371.

Rama Azhari dan Putra Kencana, 2008. Membongkar Rahasia Jaringan Cinta Terlarang Kaum Homoseksual. Jakarta: Hujjah Press.

16 RAHEEMA: J urnal Studi Gender dan Anak 
Ridho Ariono. 2011. Emotional Intellegence And Psychological Welbeing in Male Friendly. Gunadarma University Library: Jurnal Tidak Diterbitkan

Sari Nur Azizah, 2013. Konsep Diri Homoseksual di Kalangan Mahasiswa di Kota Semarang (Studi Kasus Mai hasiswa Homoseksual Di Kawasan Simpanglima Semarang). Journal Of Non Formal Education and Community Empowement. ENFECE 2(2) (2013).

Tommy Dwi Pranata, 2015. Perilaku dan Realitas Sosial Kebidupan Gay di Kota Semarang. eJournal Sosiatri Sosiologi 2015.3 (3): 135-150. Volume 3, Nomor 3.

Adelsa, 2009. Deronica. Definisi dan Proses Homoseksual. http://www.epsikologi.com/epsi/artikel detail.asp?id=551 (diakses 18 September2013)

Alhamdu, Orientasi Seksual : Faktor, Pandangan Kesehatan dan Agama. https://www.google.co.id/?gws $\mathrm{rd}=\mathrm{ssl} \# \mathrm{q}=$ dampak + homoseksual + pada + kesehatan + jurnal

Veronica Adesla, 2014. Resiko yang Rentan Dihadapi Oleh Homoseksual. http://www.psychoshare.com/file-522/psikologi-klinis/resiko-yang-rentan-dihadapi-olehhomoseksual.html. Diposkan tanggal 28 April 2014

journal.unair.ac.id/download-fullpapers-jurnal $\% 20$ shinstya.doc 